\title{
Rhopalum (Lathroropalum) creutzburgi spec. nov. from Nepal (Hymenoptera, Crabronidae)
}

\author{
With 26 figures \\ HANS-JOACHIM JACOBS ${ }^{1,2}$ \\ ${ }^{1}$ Dorfstraße 41, 17495 Ranzin, Germany. - hajojacobs@web.de \\ ${ }^{2}$ Senckenberg Deutsches Entomologisches Institut, Eberswalder Straße 90, 15374 Müncheberg, Germany \\ Published on 2016-06-30
}

\section{Summary}

Rhopalum (Latrorhopalum) creutzburgi spec. nov. from Nepal is described. Diagnostic characters for determination of the five other species inhabiting the Asian mainland are presented.

\section{Key words}

Rhopalum, Latrorhopalum, Nepal

\section{Zusammenfassung}

Rhopalum (Latrorhopalum) creutzburgi spec. nov. aus Nepal wird beschrieben. Diagnostische Merkmale zur Abgrenzung der fünf weiteren, auf dem asiatischen Festland lebenden Arten der Untergattung Latrorhopalum TsunEKI, 1952 werden angefügt.

\section{Introduction}

15 species have been described in the subgenus Latrorhopalum Tsuneki, 1952 of the genus Rhopalum StePhens, 1829. Nine species occur in Taiwan, two in the eastern Palaearctic region (Russia, China, Japan), two in northern India, one in Tibet and one in Okinawa (Japan). A further species, Rhopalum (Latrorhopalum) creutzburgi spec. nov., is described in this paper. The new species is compared with species from the eastern Palaearctic and northern India. The species described from Taiwan and Okinawa are not treated here. Unfortunately no material of the species from the Asian continent was available for comparison except a male of $R$. laticorne. The deter- mination of the here treated species is based mainly on descriptions and keys available in the cited literature. Structure and sculpture of the integument are relatively uniform and yield no good taxonomic characters. Composition of a dichotomous key was not possible without study of specimens, because the descriptions contain different sets of characters. To enable identification, a short diagnosis of the related species is given. A key of the subgenera of Rhopalum STEPHENS, 1829 is presented by LECLERCQ (2011). 


\section{Rhopalum (Latrorhopalum) creutzburgi spec. nov.}

$\mathrm{o}^{\star}$ : Body length 9.5-10 mm. Black, pronotal lobe yellow, inner side and rear of foretibia and foretarsus brown. Mandible black, with two teeth apically. Scape (identically with antennal segment 1) black, almost with little brown spots basally and apically. Antennal segment 2 black. Underside of antennal segment 3-12 brownish yellow. Last antennal segment black and flattened. Antennal segments not otherwise modified. Thorax and pronotum densely pitted, weakly shiny. Mesopleuron and propodeum with short white setae. Remaining thorax with fine white pubescence. Clypeus with dense silver setae covering sculpture. Front of clypeus produced in the middle, with two teeth close together, laterally with small angles often covered by dense setae (Fig. 2). Front edges of pronotum acuminate. Pronotum with weak medial impression, without transverse carina. Mesonotum apically with short, sometimes indistinct longitudinal keels. Propodeal enclosure not limited by groove or carina, with short keels basally. Vertical part of propodeum with deep central furrow. Petiolus with strong longitudinal keel before it widens. Abdominal tergites with very fine microscopic pits and short greyish pubescence. Sternites 2-6 with spots of white setae apically. Foretarsomere 1 curved, weakly broadened apically (Fig. 3), innerside with a row of short spines. Forefemora with round impression inside. Midtibia with brown spot distally in front of the spur. Midtarsomere 1 mostly yellowish white, sometimes black, produced in a brownish spine apically (Fig. 4). Hindtibia strongly clubbed. Hindtarsomere 1 weakly curved, tarsomere 2 normal. Legs except tarsi with short white pubescence. Spines outside of the tibia of all legs very short and inconspicuous. Relation between length of the marginal cell on radius and maximal breath of marginal cell 1.8-2.2 (cf. Fig. 6, 8). Habitus Figs 23, 24.

i : $10 \mathrm{~mm}$. Black, pronotal lobe yellow or nearly black, inner side of foretibia and last tarsomere brown. Mandible black. Front of clypeus medially produced with two strong teeth, laterally with distinct angles (Fig. 1). Teeth of clypeus stronger than in male. Antenna black; antennal segments 5-11, sometimes base of antennal segment 12, underside brown. Pygidial plate smooth, lustrous, without pits, lateral keels straight, with short longitudinal keel basally. Sternites 2-5 with white setal tufts. Forefemora with round impression inside. Petiolus $4.5 \mathrm{x}$ as long as maximal width. Remaining sculpture and pubescence similar to male. Relation between length of marginal cell on radius and maximal breath of marginal cell 1.8-2.2 (cf. Fig. 6, 8). Habitus Figs 25, 26.

Etymology: The species is named in honour of Frank Creutzburg, the collector of the type specimens.

Holotype $0^{*}$ : Nepal, Prov. Jumla, Maharigaon, 29²0'24"N $82^{\circ} 23^{\prime} 21 " \mathrm{E}, 3345 \mathrm{~m}, 21.06 .1997$, leg. Creutzburg (coll.
Senckenberg Deutsches Entomologisches Institut Müncheberg).

Paratypes (10 $0^{\star} 0^{\star}, 4$ 우 우 in coll. Senckenberg Deutsches Entomologisches Institut Müncheberg, Jacobs, Creutzburg): $20^{\star} o^{\star}$ Nepal, Maharigaon Nörd., 29²0'24"N $82^{\circ} 23^{\prime} 21^{\prime \prime E}, 3400$ m, Weißschale, 20.06.1997, leg. Creutzburg. - 4 o $^{\star}$, 1 ㅇ Nepal, Maharigaon Nörd., 29 20'24"N 82²3'21"E, 3400 m, an Euphorbia spec., 20.06.1997, leg. Creutzburg. - 1 ㅇ Nepal, Maharigaon Nörd., 29²0'24"N 82²3'21"E, $3400 \mathrm{~m}, 20.06 .1997$, leg. Creutzburg. - 1 ๙, 2 우 우 Nepal, Distr. Bajura, ca $15 \mathrm{~km} \mathrm{~S}$ Simikot, $4100 \mathrm{~m}$, Malikasthan, $29^{\circ} 50^{\prime} 42^{\prime \prime} \mathrm{N} 81^{\circ} 47^{\prime} 25^{\prime \prime} \mathrm{E}, 07.07 .2001$, leg. Creutzburg. - $10^{\top}$ Nepal, Prov. Karnali, Umg. Tamti, 2500-4000 m, 09.-12.06.2007, leg. Creutzburg. - 1 o $^{\text {* }}$ Nepal, Prov. Karnali, Churta E, Hochtal, 3500-3800 m, 02.06.2007, leg. Creutzburg. - $10^{\star}$ Westnepal, Umg. Kaigaon, 2906'43"N 82³5'32"E, 3000 m, 04.06.1997, leg. Creutzburg.

\section{Diagnosis of species}

\section{Rhopalum (Latrorhopalum) creutzburgi spec. nov.}

†: Pronotal lobe yellow, sometimes strongly reduced. Innerside of foretibia and tarsomere 5 brown. Antennal segments 5-11 and sometimes base of antennal segments 12 brown. Front edges of pronotum acuminate. Front edge of clypeus in the middle produced into two strong teeth, with distinct angles laterally (Fig. 1). $10 \mathrm{~mm}$.

$\sigma^{\star}$ : Pronotum black. Pronotal lobe yellow. Foretibia and and foretarsus brown. Antennal segments 4-12 brown underneath, without modifications. Last antennomere broadened and flattened. Clypeus with two teeth in the middle of the front margin and one small tooth on each side (Fig. 2). Foretarsomere 1 weakly curved and slightly broadened apically (Fig. 3), not broadened in frontal view. Midtarsomere 1 produced in a brownish spine apically (Fig. 4), mostly yellowish white, sometimes darkened. Marginal cell normal (cf. Fig. 6, 8). 9.5-10 mm.

\section{Rhopalum (Latrorhopalum) expeditionis LECLERCQ, 1955}

LeClercQ (1955): Tibet (Tasam, Rongshar valley). LECLERCQ (2011): listed.

$o^{\star}$ : Black. Pronotum behind, foretarsomere and midlegs yellow. Mandible dark brown. Tegula brown. Front rim of clypeus hardly produced, nearly regularly convex, without lateral angles. Basal and median antennomeres modified (Fig. 5). Submarginal cell normal (Fig. 6). Body length $7.5 \mathrm{~mm}$. Known only from the holotype, a male from Tibet (Tasam, Rongshar valley) [Ronxar Township in Tingri County, $\left.28.476^{\circ} \mathrm{N} 87.217^{\circ} \mathrm{E}\right]$. 


\section{Rhopalum (Latrorhopalum) iridescens TURNER, 1917}

Turner (1917): Kashmir (Gulmarg). - LeCLerCQ (1955): as Rhopalum (Latrorhopalum) iridescens (figure of antenna and marginal cell). - LECLERC (2011): listed, description.

$\sigma^{*}$ : Black. Outside of scapus, pronotal lobe, a large spot on the forefemur below, tarsus of forelegs and midlegs yellow. Front angle of pronotum rounded. Flagellum slender, antennal segments 5-6 modified (Fig. 7) (see LeClercQ 1955), but Turner (1917) didn't note this character. Submarginal cell normal (Fig. 8). Smaller species, body length $6 \mathrm{~mm}$. Known only from the holotype, a male from Kashmir (Gulmarg, $34.047^{\circ} \mathrm{N}$ $\left.74.386^{\circ} \mathrm{E}\right)$.

\section{Rhopalum (Latrorhopalum) laticorne (TSUNEKI, 1947)}

Gussakovskij (1932) as Crabro latronum: Ussuri area (Sedanka, Sutshan, Tigrovaja). - TsunEki (1947): Korea (Nansetsu-rei, Daitaku, corrected Crabro latronum sensu Gussakovskij to Crabro laticorne). - TsUnEKI (1952): key, Sakhalin (Horo). - Tsuneki (1967): Manchuria (Charbin). - Marshakov (1976): key, Vladivostok, Blagovestchensk, Sakhalin (Novoaleksandrovsk). - NEMKOv (1995): key, Irkutsky krai, Zabaykalsky krai, Amurskya oblast, Primorsky krai, Sakhalin). - Nemkov (2009): same locations as previous. - LECLERCQ (2011): listed.

Record: $10^{\top}$ Anisimovka [43.166 ${ }^{\circ} \mathrm{N} 132.793^{\circ} \mathrm{E}$ ], Litovka Mt., 900 m, 08.06.1993, leg. Taeger (coll. Senckenberg Deutsches Entomologisches Institut Müncheberg).

: Clypeus medially produced, with two obtuse teeth medially and a distinct tooth laterally (Fig. 12). Antennal segment 3 about $1.5 \mathrm{x}$ longer than antennal segment 4 . Petiolus stout, $4 \mathrm{x}$ long as maximal width. Body length 7.5-10 mm.

$\sigma^{\star}$ : Antennal segments 7-12 strongly broadened (Fig. 13). Scape and antennal segments 4-13 yellow or reddish yellow. Foretarsomere 1 strongly broadened (Fig. 14) and curved (Fig. 15). Midtarsomere 1 strongly angularly extended apically (Fig. 16). Clypeus without sharp teeth (Fig. 11). 7.5-10 mm. Southeast Siberia, Korea, Manchuria.

\section{Rhopalum (Latrorhopalum) latronum (KoHL 1915)}

Koнl (1915): Japan (Kofou). - Tsuneki (1952): Japan (Kyoto, Nagano, Fukushima, Tochigi, Shikoku, Sapporo, Jozankei, Sounkyo), Sakhalin (Tarandomari), Kurile Islands (Horomuchiro). - MARshakov (1976): key, Chitinskaya oblast, Sakhalin (Novoaleksandrovsk), Kurile Islands (Kunashir). - Nemkov (1995): key, South Khabarovsk, Primorsky krai, Sakhalin, Kurile
Islands (Kunashir). - Nemкov (2009): Zabaykalsky krai, Khabarovsky krai, Sakhalin, Kurile Islands (Kunashir). LECLERCQ (2011): listed.

ㅇ: Apical margin of clypeus truncate, laterally without sharp teeth (Fig. 18). Antennal segments 3 as long as antennal segment 4 or somewhat longer. Petiolus slender, $5 \mathrm{x}$ as long as maximal width. Body length 7.5-9.5 mm.

$\sigma^{*}$ : Front margin of clypeus slightly produced, nearly straight (Fig. 17). Antennal segments 7-12 normal, antennal segments 3 and 5 emarginated (Fig. 19). Foretarsomere 1 broadened in frontal view and emarginated basally (Fig. 20), in lateral view slightly curved and laterally produced in a spine (Fig. 21). Midtarsomere 1 strongly curved (Fig. 22). 7.5-9.5 mm. Southeast Siberia, Sakhalin, Kurile Islands, Japan.

\section{Rhopalum (Latrorhopalum) nursei nom. nov.}

Nurse (1902) as Crabro petiolatus: North India (Shimla). - LeClercQ (1955): as Rhopalum (Latrorhopalum) petiolatum (figure of antenna and marginal cell). LECLERCQ (2011) as Rhopalum petiolatum: description lectotype + .

New name for Crabro petiolatus Nurse, 1902 nec Crabro petiolatus PANzer, 1797, a synonym of Mellinus crabroneus (Thunberg, 1791) (see PULAWski 2016).

+ : Black. Pronotal lobe and base of scape yellow. Front edges of pronotum acuminate. Apical margin of clypeus weakly produced, without teeth. Antenna without special features (Fig. 10). Submarginal cell conspicuously short (Fig. 9). Body length $7 \mathrm{~mm}$. Only types known from north India (Shimla, $31.105^{\circ} \mathrm{N} 77.173^{\circ} \mathrm{E}$ ).

NURSE (1902) described the species based on males and females, but there is no indication of the number of specimens. The relatively short description contains no differences between the sexes. LECLERCQ (2011) designated a female as lectotype. The figures in the paper of LECLERCQ (1955) contain no indication of the sex. Maybe it was a female (see LeCLERCQ 2011). The other figures published by LECLERCQ (1955) are definitely of males. In the papers (LECLERCQ 1955, 2011) is no reference to a male. Maybe it is the unknown female of Rhopalum iridescens (see LECLERCQ 2011). 


\section{Acknowledgement}

I'm highly indebted to Frank Creutzburg (Jena) for making the material available, Stephan M. Blank (Müncheberg) for use of a Leica DFC450 C camera attached to a Leica Z6 APO zoom system and Andrew D. Liston (Müncheberg) and Christian Schmid-Egger (Berlin) for correcting the English and critical reading of the manuscript.

\section{Literature}

GussakovskiJ, V. V. 1932: Verzeichnis der von Herrn Dr. R. Malaise im Ussuri und Kamtschatka gesammelten aculeaten Hymenopteren. - Arkiv för Zoologi 24A (No. 10): 1-66.

Kohl, F. F. 1915: Die Crabronen (Hymenopt.) der paläarktischen Region. Monographisch bearbeitet. Annalen des k. k. Naturhistorischen Hofmuseums 29: 1-453, pls. I-XIV.

LECLERCQ, J. 1955: Rhopalum (Latrorhopalum) expeditionis, Crabronien nouveau du Thibet (Hym. Sphecidae). - Bulletin \& Annales de la Société Royale d'Entomologie de Belgique 91: 196-198.

LeClercQ, J. 2011: Hyménoptères Crabroniens d'Asie du genre Rhopalum STEPHENs 1829 (Hymenoptera: Crabronidae: Crabroninae). - Faunistic Entomology - Entomologie Faunistique 63: 3-21.

Marshakov, V. G. 1976: Obzor rodov triby Crabronini (Hymenoptera, Sphecidae) fauny SSSR. Rod Rhopalum STEPHENS, 1829. - Review of the genera of the tribe Crabronini (Hymenoptera, Sphecidae) from the USSR. The genus Rhopalum StePhens, 1829. Trudy Zoologicheskogo Instituta Akademii Nauk SSSR 67: 100-112.

Nemкov, P. G. 1995: Superfam. Sphecoidea. 67. Fam. Sphecidae - Digger wasps. Triba Crabronini. 425-453. - In: LeHr, P. A. (ed.): Key to the insects of Russian Far East. Neuropteroidea, Mecoptera, Hymenoptera. - St. Peterburg: Nauka 4 (1): 1-606.

Nemkov, P. G. 2009: Annotirovannyi katalog royushchikh os (Hymenoptera: Sphecidae, Crabronidae) aziatskoy chasti Rossii - Annotated catalogue of digger wasps (Hymenoptera; Sphecidae, Crabronidae) of Asian part of Russia. - Vladivostok, Dal'nauka: 1-193.

Nurse, C. G. 1902: New species of Indian Hymenoptera. - Indian Journal of the Bombay Natural History Society 14: 79-92.

Pulawski, W. J. 2016: Catalog of Sphecidae sensu lato (= Apoidea excluding Apidae). Last updated 19 March 2016. - Online in Internet: ww.calacademy.org/ scientists/projects/catalog-of-sphecidae. [Download 25.03.2016].

TsunEKI, K. 1947: Crabronidae-fauna of Korea (Hymenoptera). - Journal of the Faculty of Sciences, Hokkaido Imperial University (Series VI, Zoology) 9: 281-295.
TsuneKI, K. 1952: The genus Rhopalum Kirby (1829) of Japan, Korea, Saghalien and the Kuriles, with a suggested reclassification of the subgenera and descriptions of four new species (Hym. Sphecidae, Crabroninae). - Journal of the Faculty of Sciences, Hokkaido Imperial University (Series VI, Zoology) 11: $110-125$.

TsunekI, K. 1967: Further studies on the fossorial Hymenoptera from Manchuria. - Etizenia 23: 1-17.

Turner, R. E. 1917: On a collection of Sphecoidea sent by the Agricultural Research Institute, Pusa, Bihar. Memoirs of the Department of Agriculture in India. Entomological Series 5: 173-205. 

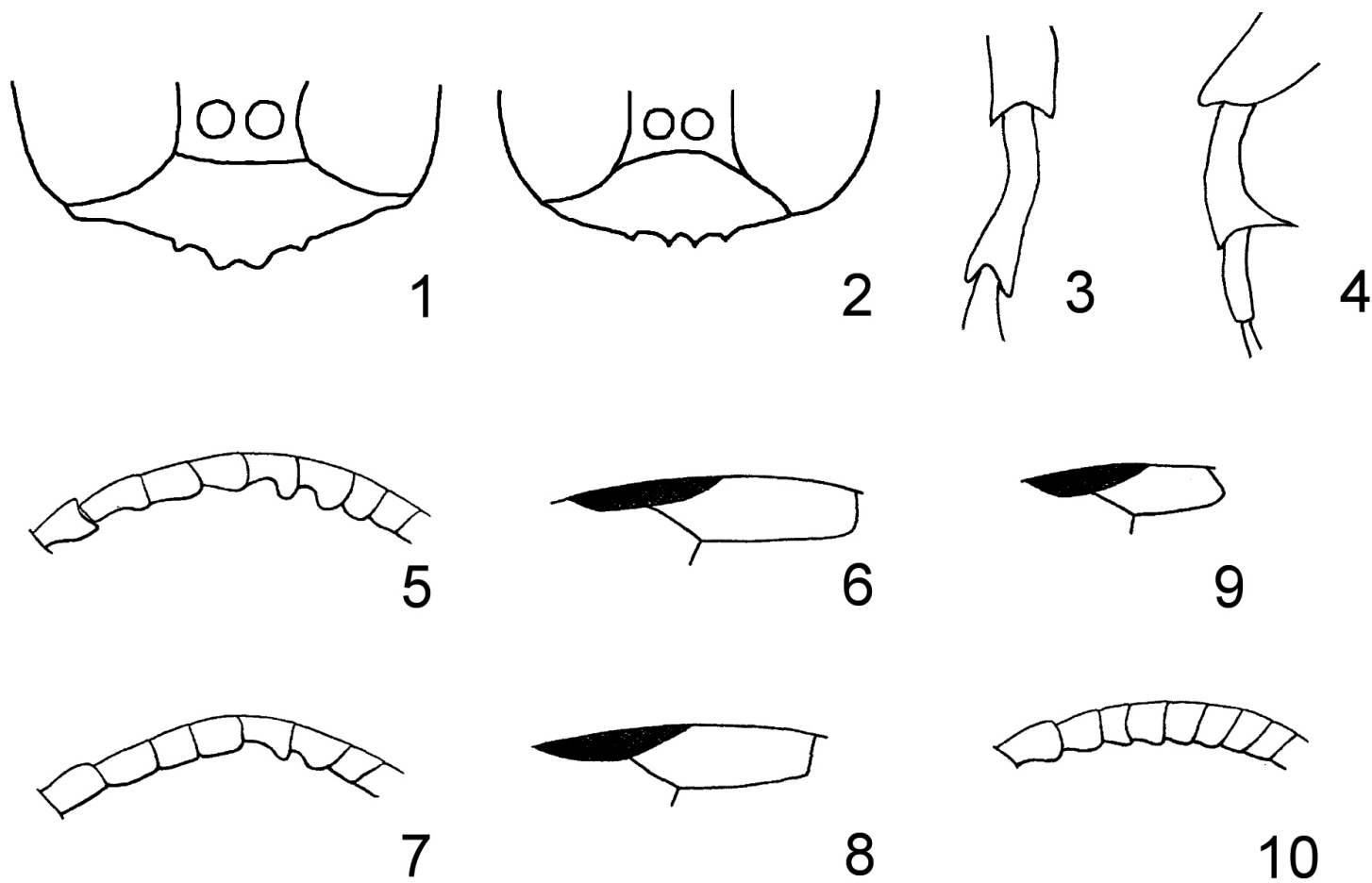

8

10
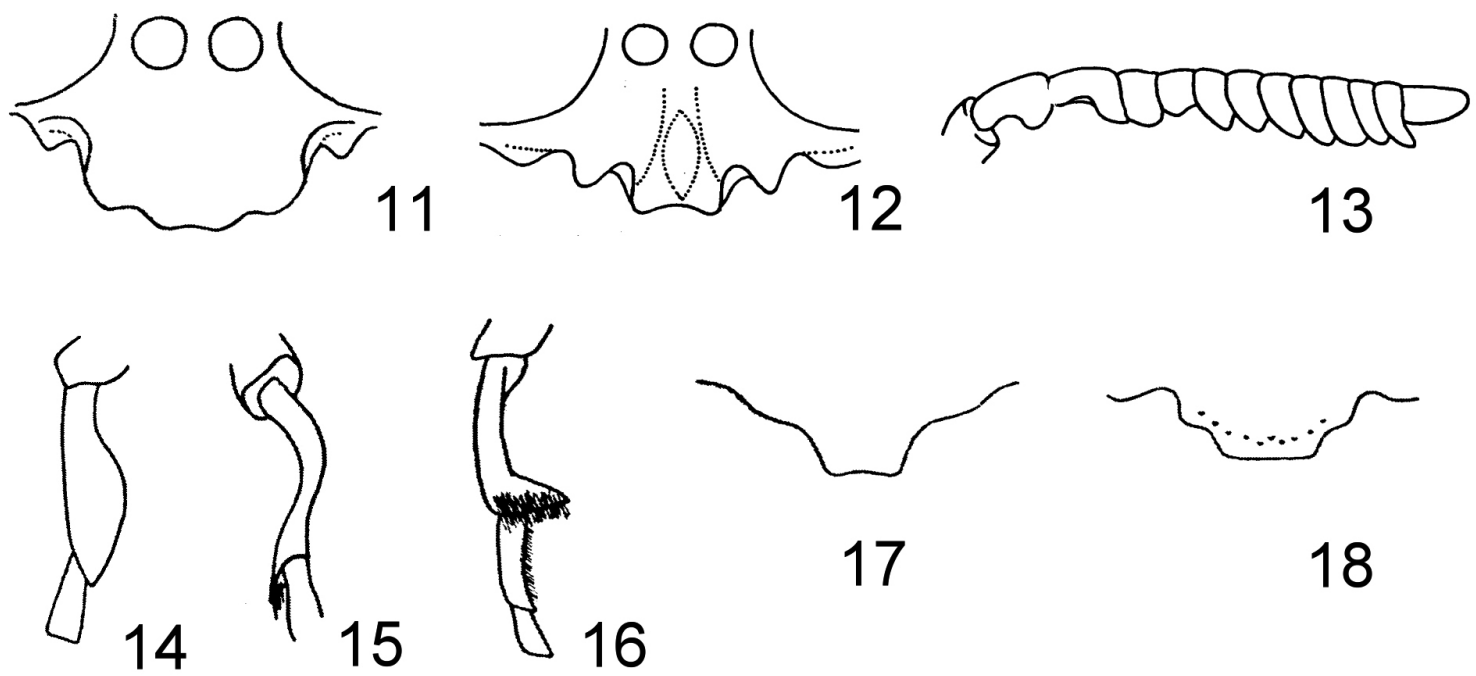

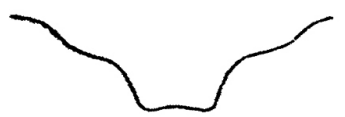

17

18

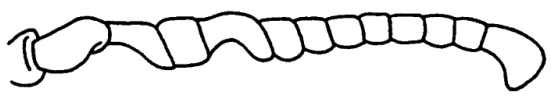

19

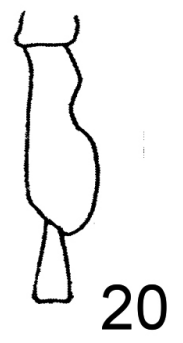

20
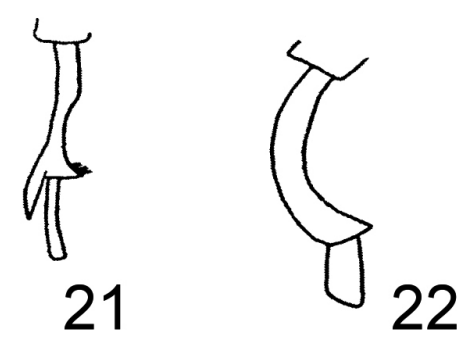

Plate 1: Fig. 1-4: R. creutzburgi: 1 - clypeus,+ 2 - clypeus $\sigma^{\star}, 3$ - tarsomere 1 of forelegs $\sigma^{\star}, 4$ - tarsomere 1 of middle legs $\sigma^{\star}$. Fig. 5-6: R. expeditionis: 5 - antenna $\sigma^{*}, 6$ - marginal cell $\sigma^{*}$.

Fig. 7-8: R. iridescens: 7 - antenna $\sigma^{\top}, 8-$ marginal cell $\sigma^{\top}$.

Fig. 9-10: R. nursei: 9 - marginal cell, 10 - antenna.

Fig. 11-16: R. laticorne: 11 - clypeus ${ }^{*}, 12$ - clypeus,+ 13 - antenna $\sigma^{7}, 14$ - tarsomere 1 of forelegs o frontal, 15 - tarsomere 1 of forelegs $\sigma^{\top}$ lateral, 16 - tarsomere 1 of middle legs $+\sigma^{\star}$.

Fig. 17-22: R. latronum: 17 - clypeus $\sigma^{\star}, 18$ - clypeus,+ 19 - antenna $o^{\star}, 20$ - tarsomere 1 of forelegs $o^{t}$ frontal, 21 - tarsomere 1 of forelegs $\sigma^{\star}$ lateral, 22 - tarsomere 1 of middle legs $\sigma^{\star}$. (Fig. 1-4 original, 5-10 after LeCLERCQ, 11-22 after MarshaKov). 

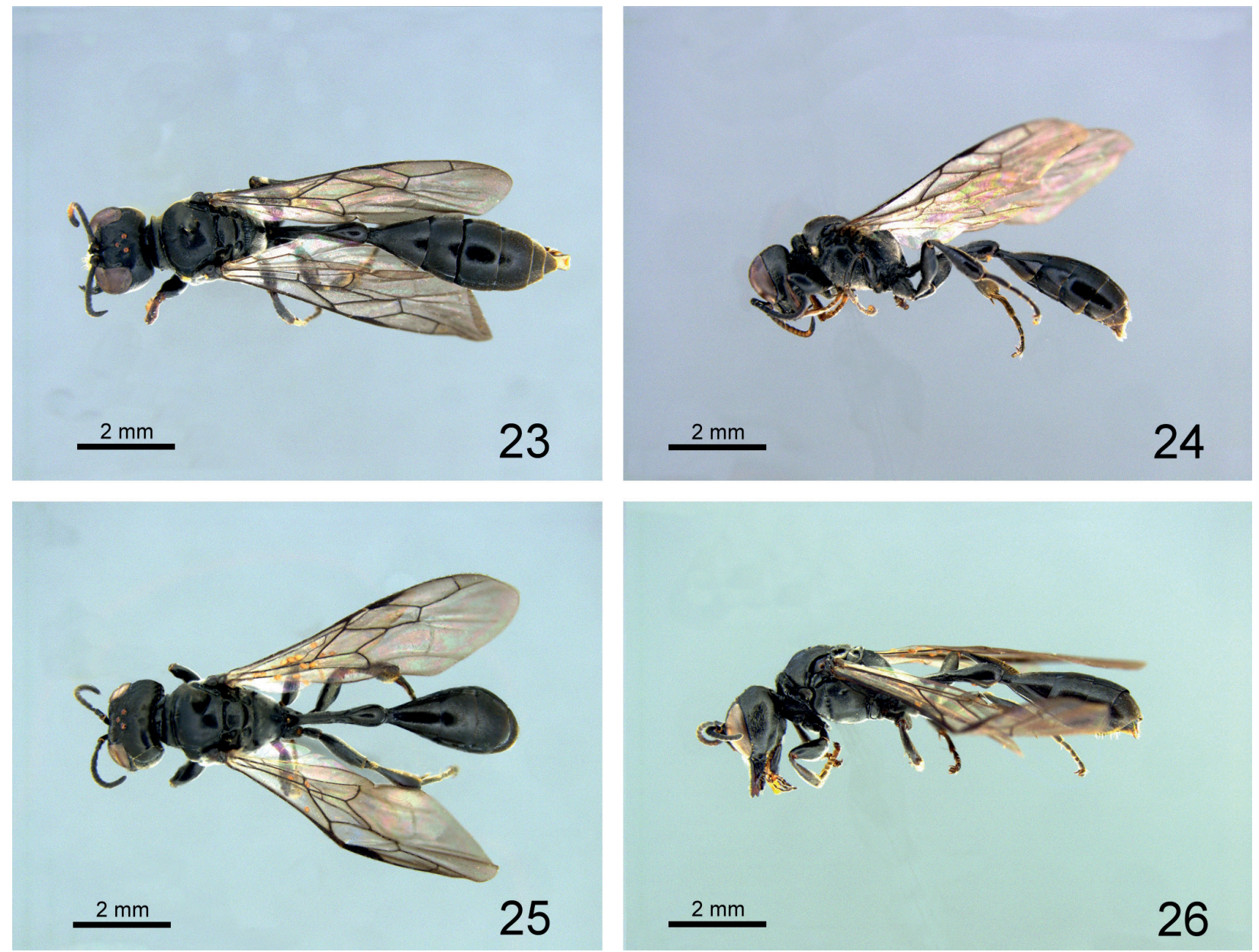

Plate 2: Fig. 23-26: R. creutzburgi habitus. 23 - $\sigma^{\top}$ holotype dorsal, $24-\sigma^{\star}$ paratype lateral, 25 - + paratype dorsal, $26-\uparrow$ paratype lateral. (Photos: JACOBS). 